\title{
PENINGKATAN KEMAMPUAN GURU-GURU MA CAHAYA HARAPAN MELALUI PELATIHAN PEMBELAJARAN BLENDED LEARNING BERBASIS LMS MOODLE DI ERA POST COVID-19
}

\author{
Ratni Purwasih ${ }^{1}$, Yanuarti Apsari \\ ${ }^{1}$ Fakultas Pendidikan Matematika dan Sains, IKIP Siliwangi \\ ${ }^{2}$ Fakultas Pendidikan Bahasa, IKIP Siliwangi \\ Email: ratnipurwasih61@gmail.com,yanuar.apsari1@gmail.com
}

\begin{abstract}
The application of e-learning is one of the learning technology innovations that integrate information and communication technology with lesson content. Although e-learning can be used independently by students, the existence of teachers is very meaningful as adults who function to support and assist students in the learning process. Therefore, a learning model that combines (blending) the face to face learning method with e-learning in an integrative and systematic manner will make the learning process more meaningful. The outbreak of the Corona virus in Indonesia has directed the learning situation to online learning. However, the fact is that the use of technology is still very minimal in schools. The same thing was found in the Mitra school. MA Cahaya Harapan is a partner school for this PKM workshop, where most teachers have not maximally utilized the use of ICT in the learning process in the classroom. The stages of this workshop include the stages of preparation, implementation, evaluation and mentoring. The purpose of this mentoring and training workshop is to improve the abilities of teachers in Moodle LMS-based blended learning in the post-Covid-19 era. Participants in this PKM consisted of 25 people and was held for three days and continued with mentoring for two consecutive weeks. Based on the results of the satisfaction questionnaire, there was a $28 \%$ increase of the participants ability after joining the training. All participants seemed very enthusiastic in participating the training program. This can be seen from the attendance of all participants from the start of the activity to the end of the activity. Participants are able to create and design Moodle LMS based blended learning.
\end{abstract}

Keywords: Blended Learning, LMS Moodle, Post Covid 19

\begin{abstract}
ABSTRAK. Penerapan e-learning merupakan salah satu inovasi teknologi pembelajaran yang mengintegrasikan teknologi informasi dan komunikasi dengan konten pelajaran. Meskipun e-learning bisa digunakan secara mandiri oleh siswa, namun eksistensi guru menjadi sangat berarti sebagai orang dewasa yang berfungsi memberi dukungan dan mendampingi siswa dalam proses pembelajaran. Oleh karena itu, model pembelajaran yang menggabungkan (blending) metode face to face learning dengan e-learning secara integratif dan sistematis akan membuat proses pembelajaran menjadi lebih bermakna. Kejadian virus Corona yang mewabah di Indonesia membuat situasi belajar diarahkan ke online learning. Akan tetapi faktanya penggunaan teknologi masih sangat minim ditemukan di sekolah. Hal yang sama juga ditemukan di sekolah Mitra. MA Cahaya Harapan merupakan sekolah mitra untuk tempat workshop pengabdian ini, dimana kebanyakan guru belum dengan maksimal memanfaatkan penggunaan ICT ini pada proses pembelajaran di kelas. Tahap-tahapn pengabdian ini meliputi tahap persiapan, pelaksanaan, evaluasi dan pendampingan. Tujuan workshop pendampingan dan pelatihan ini adalah meningkatkan kemampuan guru-guru dalam pembelajaran blended learning berbasis LMS Moodle di era post Covid-19. Peserta dalam PKM ini terdiri dari 25 orang dan dilaksanakan selama tiga hari dan dilanjutkan pendampingan selama dua pekan berturut-turut. Berdasarkan hasil angket kepuasaan sebesar $28 \%$ peningkatan kemampuan peserta dari sebelum pelatihan. Seluruh peserta terlihat sangat antusias dalam mengikuti program pelatihan. Hal ini bisa dilihat dari kehadiran seluruh peserta mulai dari awal kegiatan sampai akhir kegiatan. Peserta mampu membuat dan mendesain pembelajaran blended learning berbasis LMS Moodle.
\end{abstract}


Kata Kunci: Blended Learning, LMS Moodle, Post Covid 19

\section{PENDAHULUAN}

Fenomena belajar online atau home learning yang di instruksikan oleh kepala daerah masing-masing di wilayah jawa barat dalam rangka mencegah penyebaran virus Corona atau Covid-19 menjadi trend tersendiri di awal tahun 2020. Oleh karena itu, guru dan siswa harus memiliki kemampuan untuk belajar online dan blended learning. Melalui pelatihan dan pendampingan team kami, guru-dan siswa mampu mengimplementasikan aplikasi yang mendukung blended learning.

Oleh karena itu, pendidikan di Sekolah salah satunya bertujuan untuk mempersiapkan SDM yang memiliki keterampilan dan pengetahuan sesuai dengan kebutuhan persyaratan lapangan kerja. Dan kualitas siswa itu tidak dapat dipisahkan dari peranan seorang guru. Karena guru mempunyai peran yang dominan dalam meningkatkan kompetensi siswa. Salah satu indikator guru profesional dan kompeten adalah guru yang mampu beradaptasi dengan perkembangan keilmuan yang hari demi hari semakin canggih. Selain itu, guru yang profesional dan kompeten juga harus mampu menerapkan model dan metode pembelajaran berdasarkan tuntutan waktu dan kebutuhan peserta didik. Penerapan pola ini akan menciptakan suasana menyenangkan dalam belajar, yang pada akhirnya akan menghasilkan proses kegiatan belajar mengajar yang berkualitas dan menciptakan peserta didik yang berprestasi. Sehingga dapat disimpulkan bahwa kompetensi guru akan menentukan mutu lulusan suatu pendidikan (Apsari, Lisdawati \& Mulyani, 2020).

Di era globalisasi ini, tuntutan seorang guru sangat tinggi. Guru diharapkan mampu mendesain pembelajaran yang menarik sesuai dengan karakteristik siswa zaman sekarang. Saat ini Sistem Information and Communication Technology (ICT) sudah bukan merupakan barang baru lagi, dikalangan anakanak media internet sudah cukup familiar. Hal ini terbukti dari banyaknya peserta didik mulai dari tingkat SD, SMP dan SMA yang memiliki e-mail. Facebook, twitter, instagram dan juga blog. Saat ini hampir setiap siswa dapat mengakses internet dengan mudah dan cepat. Akan tetapi jika kemampuan siswa dalam menguasai aplikasi internet ini tidak dibarengi dengan tingginya kemampuan guru dalam menggunakan internet, proses pembelajaran akan menjadi sangat membosankan. Oleh karena itu, pelatihan dan pendampingan bagi guru-guru di MA Cahaya Harapan dianggap perlu untuk dilaksanakan. Guru-guru MA Cahaya Harapan akan diberikan pelatihan dalam mendesain dan menerapkan model pembelajaran blended learning untuk meningkatkan kualitas pembelajaran.

Blended Learning merupakan sebuah pendekatan pembelajaran yang memadukan kelebihan pada pembelajaran tatap muka dan $e$ learning. Dalam pembelajaran tatap muka, peserta didik bisa bertemu langsung dengan 
pendidik. Oleh karena itu, interaksi sosial bisa tetap terjadi didalam kelas dimana peserta didik memang masih perlu panduan dalam pembelajaran (Akkoyunlu dan Soylu, 2006: 45).

Pembelajaran online menawarkan pembelajaran sepanjang waktu dimana pembelajaran bisa diakses kapan saja dan dimana saja (Akkoyunlu dan Soylu, 2008: 183).

Hameed et al (2008: 3) juga menambahkan bahwa materi dalam pembelajaran online bisa diakses sesering mungkin apabila terdapat sesuatu yang terlupakan. Selain itu, penggunaan teknologi juga dapat memberikan peluang bagi lingkungan belajar dan mengajar yang bermakna yang dapat memengaruhi motivasi, pemikiran kritis, dan kemandirian siswa (Padurean \& Margan, 2009, dalam Murni dan Apsari, 2021).

Oleh karena itu, menerapkan model pembelajaran Blended Learning dalam proses pembelajaran penting dilaksanakan dilihat dari segi manfaatnya.

Berdasarkan permasalahan di atas, tujuan pengabdian ini adalah meningkatkan kemampuan guru-guru MA Cahaya Harapan melalui pelatihan dan pendampingan pembelajaran blended learning berbasis LMS Moodle.

\section{METODE PELAKSANAAN}

\section{Tahap Persiapan}

Perencanaan kegiatan-kegiatan yang dilakukan pada tahap perencanaan adalah (1) pemberitahuan pada mitra. Pelaksanaan tahap ini didahului dengan mengirim surat pemberitahuan kepada pihak mitra yaitu sekolah MA Cahaya Harapan. Setelah itu dilakukan koordinasi untuk membahas teknis pelaksanaan kegiatan; (2) Penyusunan program kegiatan. Berdasarkan hasil identifikasi, hasil analisis permasalahan yang ada, hasil analisis kebutuhan, selanjutnya disusun program kegiatan. Pelaksanaan pelatihan dilakukan selama 2 hari, dengan mengundang seluruh Anggota guru-guru MA Cahaya harapan melalui zoom meeting Kegiatan meliputi pemaparan materi, workshop pembelajaran blended learning dan tanya jawab serta mengisi angket kepuasaan.

2. Tahap Pelaksanaan

Kegiatan pengabdian kepada masyarakat ini dilaksanakan pada bulan juli 2020. Pengabdian ini dilaksanakan di Sekolah MA Cahaya Harapan Cisarua melalui zoom meeting dan offline dengan memperhatikkan protokol kesehatan. Sasaran pengabdian ini adalah seluruh guruguru MA Cahaya harapan. Kenyataan dilapangan adalah sebagian guru masih belum dapat mendesain pembelajaran blended learning berbantuan elearning. Bentuk kegiatan pengabdian ini adalah pelatihan dan workshop melalui zoom meeting. Pelatihan ini dilaksanakan dalam 3 hari dan dilanjutkan pendampingan kepada peserta melalui whatsapp. Setelah pelatihan tiga hari dilaksanakan, peserta diberikan angket untuk melihat sejauhmana 
peningkatan kemampuan setelah diberikan pelatihan.

3. Kegiatan evaluasi

Kegiatan evaluasi dilakukan secara langsung oleh pelaksana. Evaluasi pelaksanaan ini berupa tes dan angket yang disebarkan kepada seluruh peserta. Proses evaluasi dilaksanakan untuk mengetahui kekurangan dan kendala dalam pelaksanaan kegiatan.

4. Pendampingan

Setelah dilaksanakan evaluasi melalui tes dan angket, guru-guru yang belum dapat mendesain dan mempraktekan media pembelajaran didampingi kembali pelatihan. Melalui pendampingan ini, guruguru dilatih kembali membuat dan mengimplementasikan media pembelajaran sampai memiliki kemampuan yang diharapkan.

\section{HASIL DAN PEMBAHASAN}

Kegiatan pengabdian ini dilaksanakan selama 3 hari berturut melalui zoom meeting dan dilanjutkan dengan pendampingan melalui whatsapp. Kegiatan pada hari pertama diawali dengan pengenalan pemamaran berkenaan dengan pembelajaran blended learning berbantuan e-learning untuk guru dan siswa. Pelatihan ini membekali peserta agar memiliki kemampuan mengajar inovatif di era pandemic atau post pandemic Covid-19. Guru diberikan cara untuk mendesain rencana pembelajaran berbasis e-learning LMS Moodle. Kegiatan pada hari kedua, peserta diberikan kesempatan untuk mencoba login ke akun e-learning LMS Moodle. Peserta mencoba membuat topic dan kursus atau pembelajaran yang diampu untuk bahan mengajar kepada siswa. Terlihat seperti berikut ini.

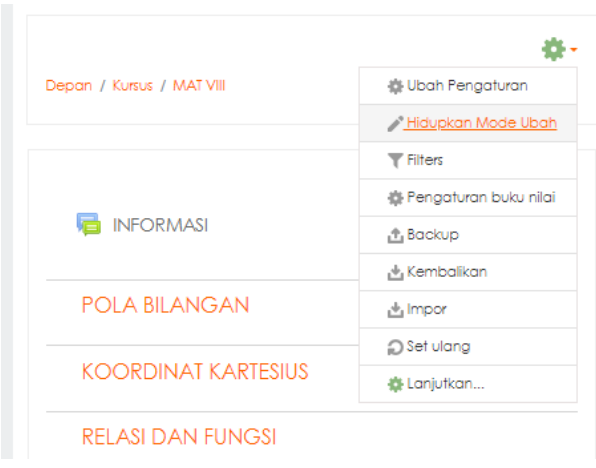

\section{Gambar 1. Kursus di E-learning Moodle}

Selanjutnya, pemberian tugas terhadap peserta yang akan dibahas pada pelatihan berikutnya sebagai bahan evaluasi pemahaman materi pelatihan. Selanjutnya, tahap evaluasi pelaksanaan pengabdian melalui kuisioner lewat google form. Setelah pelatihan, guru memperoleh pendampingan agar kemampuan menggunakan e-learning lebih mahir.

Pelaksanaan pelatihan yang pertama yaitu pelaksanaan pelatihan tentang pembelajan blended learning, LMS moodle, dan pemaparan materi penggunaan elearning LMS Moodle. Paparan materi pendahuluan mengenai apa itu blended learning, desian pembelajaran blended learning dan pengembangan pembelajaran blended learning di masa Covid-19. Selanjutnya, dilanjutkan dengan berlatih membuat bangun ruang Tiga dimensi menggunakan softwere geogebrdan 
mendesain pembelajaran blended learning untuk pembelajaran daring selama Covid 19. Setelah itu, peserta dikenalkan dan dipandu untuk belajar login ke akun e-learning LMS Moodle yang sudah siap untuk dipergunakan oleh guru dan siswa. Pelaksanaan Pelatihan yang kedua yaitu pengenalan menu-menu yang ada di LMS Moodle di website elearning tersebut. Pelatihan ini dilakukan untuk memberikan keterampilan kepada para guru dalam mengembangkan pembelajaran berbasis ICT dengan bantuan LMS Moodle. Melalui $e$ learning ini, siswa dan guru mudah untuk berinteraksi dan berkomunikasi secara maya agar proses belajar dan mengajar tetap berkualitas. Sejalan dengan Nuraeni, Purwasih, \& Mutakim (2020) bahwa “Online learning allows students to have free time to study so they can study whenever and wherever". Pelaksanaan pelatihan yang selanjutnya yaitu pendampingan untuk peserta yang belum memahami atau peserta yang ingin lebih mendalami e-learning LMS Moodle. Pendampingan dilaksanakan secara online dan offline dengan memperhatikan protokol kesehatan. Terlihat seperti pada gambar berikut ini.

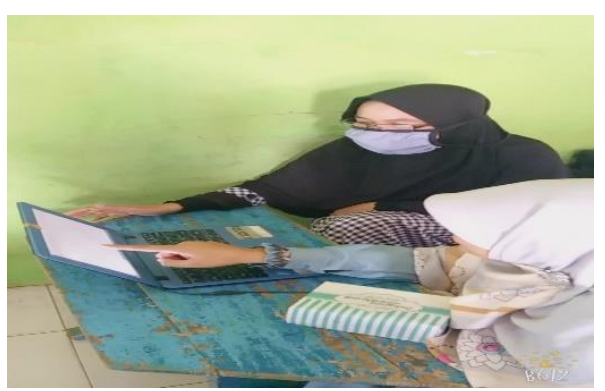

Gambar 2. Tahap Pendampingan
Tahap pendampingan ini, peserta dikelompokkan menjadi beberapa grup agar memudahkan belajar memahami materi dan praktek. Proses pendampingan ini dilakukan untuk selama 2 pekan dan setiap pertemuan peserta dibekali latihan untuk memperdalam pemahamannya. Pendampingan ini berlangsung sangat antusias dan tampak peserta bersemangat untuk sharing dan bertanya. Peserta mendengarkan dnegan baik dan seksama materi yang disampaikan oleh tutor selama kegiatan berlangsung. Guru dibimbing untuk memahami dengan baik dan benar materi tenatng e-learning ini agar mampu mengajarkan kembali kepada yang lain terutama peserta didik. Peserta juga diberikan pemahaman tentang kuis atau soal ulangan menggunakan LMS Moodle ini. Agar guru dan siswa mudah melaksanakan penilaian atau ulangan harian.

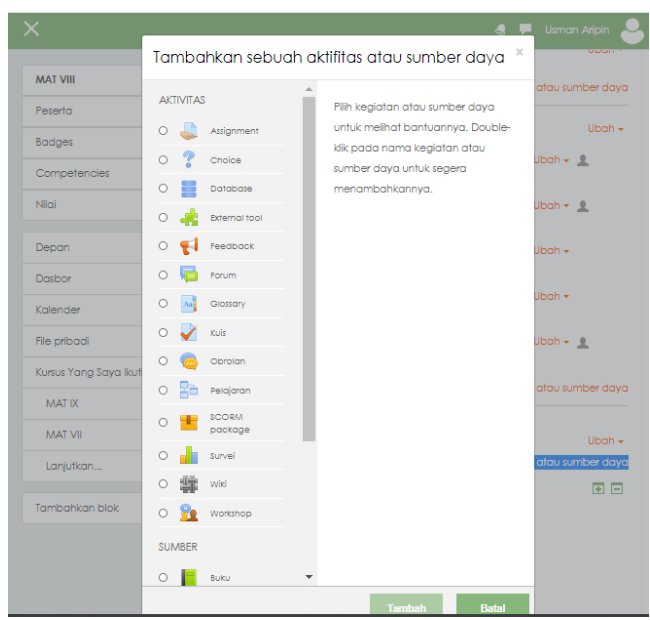

Gambar 3. Menu untuk Kuis

Pada tool bar ini lah semua aktivitas pembelajaran dimulai ada banyak fitur yang dapat digunakan disini untuk dimanfaatkan dalam pembelajaran. Secara 
umum fitur itu ada dua bentuk yaitu aktivitas dan sumber.

Peserta dan narasumber saling berkomunikasi dan diskusi menanyakan implmentasi pembelajaran blended learning berbasis LMS Moodle ini untuk memudahkan proses kegaiatan mengajar secara daring dan memberikan warna baru kepada siswa. peserta pelatihan telah dapat memanfaatkan elearning LMS Moodle ini untuk pembelajaran online yang lebih menarik. Sehingga pemahaman siswa dan motivasi siswa dalam memahami materi ajar. Selain itu, penyampaian materi secara daring nantinya akan membuat siswa lebih menarik terhadap materi yang sedang di upload ke elearning tersebut. Uraian tenatng manfaat dari elearning LMS Moodle ini alternatif Teknik mengajar matematika yang dapat menunjang guru dan siswa di era pandemic.

Peserta pelatihan diberikan modul tutorial yang berisi langkah-langkah dan panduan elearning LMS Moodle. Berikut ini adalah contoh fitur-fitur pada e-learning LMS Moodle yang yang digunakan sebagai menu untuk aktivitas pembelajaran.

Menu aktivitas obrolan memungkinkan peserta untuk berdiskusi secara sinkron waktu nyata berbasis teks. Obrolan dapat berupa aktivitas satu kali atau dapat diulang pada waktu yang sama setiap hari atau setiap minggu. Sesi obrolan disimpan dan dapat dibuat tersedia untuk semua orang untuk melihat atau dibatasi untuk pengguna dengan kemampuan untuk melihat log sesi obrolan.

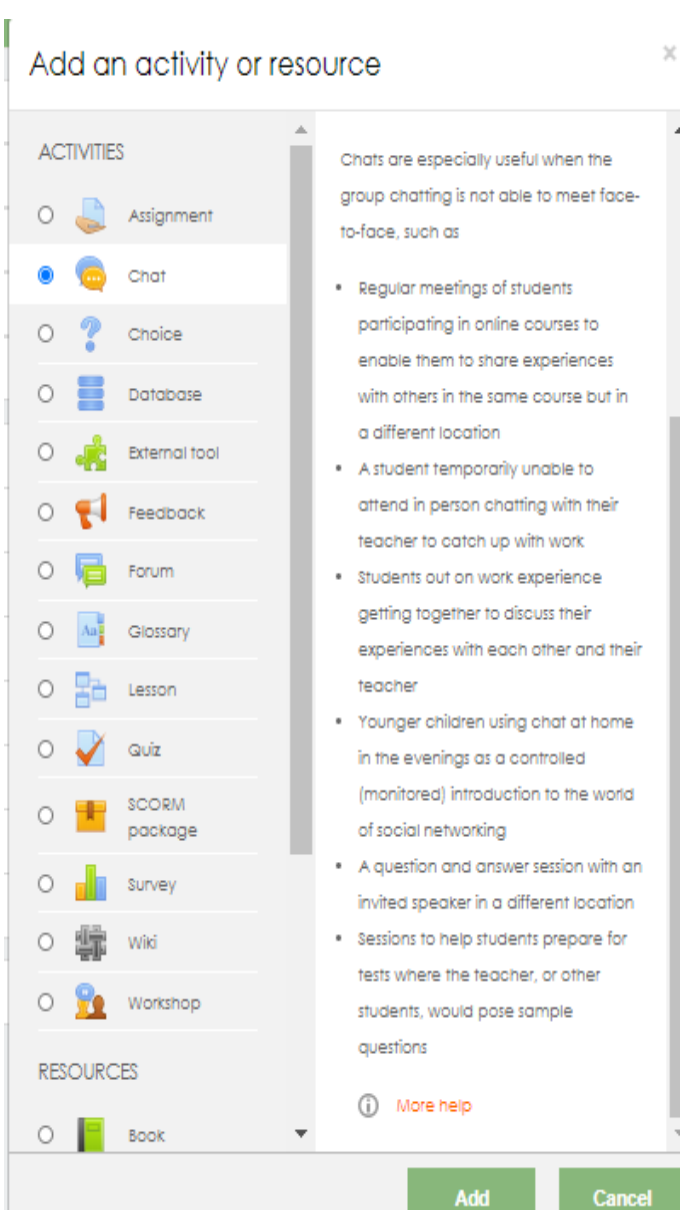

Gambar 4. Menu Aktivitas E-learning

Hampir semua guru belum pernah mengikuti pelatihan pembelajaran blended learning berbasis LMS Moodle. Tingkat kepuasan peserta pelatihan terhadap materi yang disampaikan pemateri sangat signifikan peningkatannya. Berdasarkan perhitungan di peroleh peningkatan kemampuan guruguru setelah pelaksanaan pelatihan sebesar $28 \%$ dari sebelumnya. Melalui kegiatan ini, kemampuan 
guru terasah dan siap untuk menghadapi pembelajaran daring di era new normal Covid 19.

\section{SIMPULAN}

Beberapa kesimpulan yang diperoleh dari hasil pengabdian ini adalah sebagai berikut ini:

1. Melalui pelatihan dan pendampingan pembelajaran blended learning berbasis LMS Moodle dapat membantu guru dan memberikan motivasi siswa belajar secara daring di era pandemic Covid 19

2. Pelatihan berperan penting dalam rangka meningkatkan kompetensi guru MA Cahaya Harapan dalam melaksanakan inovasi pembelajaran daring di era pandemic Covid 19.

3. Peserta antusias mengikuti program pengabdian ini dan menambah pengetahuan guru.

4. Melalui kegiatan pengabdian kepada masyarakat ini, para guru mampu berinovasi dalam pembelajaran daring agar siswa tidak jenuh.

5. Peserta pengabdian pada masyarakat ini mengalami peningkatan kemampuan sekitar $28 \%$ dari sebelumnya.

\section{DAFTAR RUJUKAN}

Akkoyunlu, B. \&Soylu, M.Y. (2006). A Study on Students' Views about Blended Learning Environment. Turkish Online Journal of Distance EducationTOJDE,7(3).

Akkoyunlu, B., \&Soylu, M. Y. (2008). A Study of Student's Perceptions in a Blended Learning Environment Based on Different Learning Styles.Educational Technology \& Society, 11(1), 183-193.

Arnita, MT., (2005). Teknologi Informasi Dalam Dunia Pendidikan. http://www.bunghatta.ac.id/artikel/54/tekn ologi-informasidalam-duniapendidikan.html.

Apsari, Y., Lisdawati, I., \& Mulyani, E. R. (2020). Pelatihan Pembelajaran Berbasis ICT Kepada Guru Bahasa Inggris. Abdimas Siliwangi, 3(2), 267-278.

Hakim, A.B. (2016). Efektifitas Penggunaan E-Learning Moodle, Google Classroom Dan Edmodo. I-STATEMENT: Information System and Technology Management, 2(1).

Hameed, S., Badii, A. \& Cullen, A.J. (2008). Effective E-Learning Integration with Traditional Learning in a Blended Learning Environment.European and Mediterranean Conference on Information System. May 25-26.

Hanum, N.S. (2013). Keefetifan ELearning sebagai Media Pembelajaran (Studi Evaluasi Model Pembelajaran ELearning SMK Telkom Sandhy Putra Purwokerto). Jurnal Pendidikan Vokasi, 3(1).

Hardiyana, Andri. (2015). Implementasi Google Classroom sebagai Alternatif dalam Meningkatkan Mutu Pembelajaran di Sekolah. Karya Tulis Ilmiah, Cirebon: SMA Negeri 1 Losari

Istiqomah, Sri Banun Titi \& Ninik Azizah. (2013). Penerapan Metode Blended Learning Berbasis ICT untuk Meningkatkan Minat dan Prestasi Belajar pada Mata Kuliah Ilmu Sosial Budaya Dasar (ISBD) di Prodi D-III Kebidanan FIK UNIPDU Jombang. Jurnal Eduhealth, 3(2), 103-113. 
Kemendikbud. (2014). Materi Pelatihan Implementasi Kurikulum 2013. Jakarta: Kementerian Pendidikan dan Kebudayaan.

Maryani, Y. (2013). Aplikasi ELearning Sebagai Model Pembelajaran Berbasis Teknologi informasi di Jurusan Kesehatan Gigi Poltekkes Kemenkes Pontianak. Vo. 9 No. 1 hal. 27-39

Munawwarah, S. F. (2014). Teachers'perceptions on the use of ICT in Indonesian EFL learning context. English Review:Journal of English Education, 3(1), 70-80.

Murni, S., \& Apsari, Y. (2021, January). VBA Microsoft Excel Sebagai Media Pembelajaran Inovatif Berbasis Ict Untuk Pembelajaran Matematika Dan Bahasa Inggris. In PROSIDING SENANTIAS: Seminar Nasional Hasil Penelitian dan Pengabdian kepada Masyarakat (Vol. 1, No. 1, pp. 10931102).

Nuraeni,L., $\quad$ Purwasih,R., \& Mutakim, J. (2020). IKIP Siliwangi student's perceptions of online teaching and learning process during COVID-19 pandemic?. IOP Conf. Series: Journal of Physics: Conf. Series, 1657 (012084),1-6. Peraturan Menteri Pendidikan dan Kebudayaan tahun 2013 tentang Standar Proses Pendidikan Dasar dan Menengah.

Pradana, D.B.P \& harimurti, R. (2017). Pengaruh Penerapan Tools Google Classroom pada Model Pembelajaran Project Based Learning terhadap Hasil Belajar Siswa. Jurnal IT-Edu Universitas Negeri Surabaya,2 (1).

Salinan Inpres No.9 Tahun (2016). https://kemdikbud.go.id/main/files/downlo ad/e451d9ec3a04121doi:10.1088/17426596/1657/1/012084. 